\title{
Major Challenges of Adopting International Financial Reporting Standards in Ethiopia
}

\author{
Zewdu Eskezia Gelaye, (Lecturer) \\ College of Business and Economics, Department of Accounting and Finance, Dambi Dollo \\ University, Dambi Dollo, Ethiopia
}

\begin{abstract}
International Financial Reporting Standards (IFRS) are a set of Accounting Standards developed by the International Accounting Standard Board (IASB). The major objective of this study is to determine the major challenges of adopting international financial reporting standards by firms. To achieve this objective a systematic review of meta-analysis method was used. The findings of the study shows that complexity of financial reporting, lack of availability of competent specialist and high level of training costs are major challenges of IFRS adoption in different countries. Based on the findings of the study the researcher recommends that before implementing IFRS stake holders should consider the availability of adequate resources to support the sustainable implementation of IFRS in Ethiopia.
\end{abstract}

Keywords: Challenge, IFRS, adoption, comlexity, training

DOI: $10.7176 / \mathrm{RJFA} / 10-21-01$

Publication date: November $30^{\text {th }} 2019$

\section{Introduction}

1.1 Background of the study

In the past few years, many developed and developing countries have adopted International Financial Reporting Standards (IFRSs) as their basis for financial reporting. The European Union (EU) took the lead when she mandated all listed companies in the European Union to start the adoption and implementation of the IFRS in their financial reporting since 2005. In fact the year 2005 to 2009 was regarded by the IASB to provide a stable platform for EU companies that started implementation in 2005. Presently over 120 countries are reported to have adopted or converged with IFRS. IFRSs are a set of accounting principles that are rapidly gaining acceptance on a worldwide basis. They are published by the London-based International Accounting Standards Board (IASB). IFRS is more focused on objectives and are principle based. They purport to be a set of rules that ideally would apply equally to financial reporting by public companies worldwide. The adoption of IFRS as issued by the International Accounting Standards Board (IASB) is expected to result in the application of a common set of financial reporting standards within and between countries in Europe and many other countries that require or permit application of IFRS. However, comparability is unlikely to arise from IFRS adoption (Ball, Robin \&Wu, 2000; Christensen Lee \& Walker 2008; Sunders, 2010). Specifically, Ball, (1 995, p29) concludes that "internationalization will reduce some or much of the diversity in accounting rules and practices across nations; it will not eliminate it nor should it". Ball, (2006) expresses concerns that the application of IFRS will not be uniform and that will affect the reporting and perception of IFRS quality by users. For countries wishing to adopt IFRS Sunder, (2010) proposes six bases for decision as : contribution to prosperity and wealth of society, inclusion of relevant information from all parts of the economy, stability over time, adaptability to changes in economic environment, robustness against manipulations, and resistance to capture by narrow interest groups. The debates of IFRS adoption is not only about the benefits and costs but also the global financial reporting convergence implications if IFRS were modified as a result of the adoption process

The transition to IFRS for the companies in these countries has considerable costs. There are technical and training costs that are incurred that may cause several companies to be cautious in implementing these changes. However, the benefits are numerous and worth it.

Literature on IFRS adoption by countries has received academic attention. An interesting discussion regarding this adoption (partial or total change from the national accounting standard to international standard) is the one concerning to high quality, understandable and applicable IFRS to be worldwide accepted, according to the proposal of the International Accounting Standards Board (IASB) (Ball, 2006; IASB, 2005). This discussion becomes even more relevant as the results presented in the literature on IFRS adoption and accounting quality are not unanimous. According to the investigation of Jeanjean \& Stolowy, (2008) that analyzed the effect of the mandatory adoption of IFRS in the quality of earnings, more precisely on performance management, shows that following the standards is not sufficient to create a common language of business. Jeanjean \& Stolowy, (2008) also state that incentives for management and national institutional factors play an important role forming the characteristics of financial reporting. The accounting system in each country is a cultural, economic history and political product incorporated into each own beliefs, influenced by the way each country interprets and adopts the IFRS standards (Chand \& Patel, 2008; Guerreiro, Rodrigues, \& Craig, 2011). Although there are significant 
benefits of adopting international financial reporting standards, it is not also without problems.

According Jermakowicz, (2004) IFRS conversion has many challenges such as increased volatility of earnings, high cost of implementation, Complex nature of IFRS and problems related to the implementation guidance.

The adoption and implementation of international standards in a country takes place in an environment that is affected by factors unique to that country; for example the economy, politics, laws and regulations and cultures.

Bhargava \& Shikha, (2013) argued that IFRS does not require strict reporting rules; hence, it is a principlebased standard. The principle-based characteristic of IFRS is a demerit, as reporting entities can easily manipulate the financial report through creative accounting. IFRS is, however, a fair-value, principle-based standard with the potential to improve reporting qualities, enhance international comparability, exhibit more information disclosure, and increase transparency of accounting information. A number of studies have argued that cross-border contagion arises as markets become more integrated. Based on this, the reviewer briefly summarize the literature and evidence on IFRS adoption and cross-border equity market investment in the modern day accounting records financial statement. Depending on the general economic situation, existing regulatory framework and financial reporting tradition of a given country, practical adoption of IFRS poses considerable challenges and prospects.

More recently (Ahmed, Neel \& Wang, 2013) have found that accounting accuracy declined after mandatory adoption of IFRS, unlike previous studies have shown, highlighting an increase in the quality of accounting after the adoption of IFRS. Thus the objective of this paper is to analyze the challenges of Adopting International Financial Reporting Standards.

\subsection{Statement of the Problem}

In recent years, the development of international accounting standards and adoption by such industrialized countries as: Britain, Germany, United States of America, Canada and the members of the European Union have been a major of concern among accounting professionals. In spite of the numerous studies about the Adoption of International Financial Reporting Standards by developed and industrialized countries around the world, less attention has been given to developing countries. Virtually, no articles and books about the adoption of accounting standards by developing countries and in particular Ethiopia exist (Zeghal \& Mhedhbi, 2006). Moreover, the few that are in existence primarily focuses on whether it is necessary for developing countries to adopt international accounting standards (Tyrrall et al, 2007).

Lack of empirical studies on the association between change in accounting standards convergence and accounting quality of financial institutions such as banks in terms of earnings management and value relevance is theoretically and practically precarious giving the functional status of financial institutions particularly banks is one sector that is expected standards specifically IFRS adoption (Olano et al, 2014). According to (IASB, 2014) as cited in (Olano etal, 2014) moving to IFRS has had a major challenge on the reporting requirements of financial institutions.

Many studies are conducted around the title of challenges of IFRS implementation adoption in different parts of the world. And from these;

Atu \& Raphael, (2016) conducts a study on the title of challenges of the implementation of IFRS in less developed countries and founds that political, legal, cultural, financial and economical aspects are challenging for IFRS adoption in less developed countries. Mohamed Z, (2014) study on the title of challenges of international financial reporting standards (IFRS) adoption in Libya and indicates that IFRS adoption by Libyan companies has faced some obstacles such as accounting education and economic issues. Demaki, (2013) examines prospects and challenges of IFRS to economic development in Nigeria and the findings of the study shows that need of amendment of laws and regulation is among the major challenges and from the benefits enhanced effectiveness of management function is the major one. (Tesfu,2012) studies the benefits and challenges of adoption IFRS in Ethiopia and found that need for training, complexity of IFRS and lack of implementation guidance are the major challenges of IFRS adoption. (Mihiret,2016) investigates the process, issues and Implications of IFRS adoption in Ethiopia. The study shows that lack of commitment and low capacity among accounting professional and lack of coordination of all concerned stakeholders are the major challenges. (Alemi, 2016) conducts a research on IFRS adoption progress in Ethiopia and founds that shortage of qualified professionals and lack preparedness are the major challenges of IFRS adoption, Fikru, (2012) has conducted a study on the title of the adoption of international financial reporting standards (IFRS) in Ethiopia: and founds that High cost of adopting, the complex nature, lack of proper instructions from regulatory bodies for implementing IFRS, as well as IFRS's emphasis on fair value accounting, are listed among the most important challenges of IFRS adoption

As the best knowledge of the researcher previous studies in Ethiopia have not included inadequate knowledge of professional accountants, IFRS adoption complexity IFRS implementation cost as the main 
variable of their studies. So, the researcher has taken up this study to test the combined effects of these variables on IFRS adoption, adopt and face the practical challenges. The actual problems regarding the challenges of absence of finding source documents and data to satisfy IFRS requirements as well as resources and infrastructure accessible for adoption has yet to be studied in the context of Ethiopia. Thus the researcher addresses the following research questions.

\subsection{Research questions}

- What are the effects of inadequate knowledge of professional accountants on IFRS adoption?

- What are the effects of international financial reporting systems complexity on its adoption

- What are the effect of implementation cost on IFRS adoption?

\subsection{Objectives of the Study \\ 1.4.1. General Objective}

The major objective of this study is to determine the major challenges of International Financial Reporting Standards adoption.

\subsubsection{Specific Objectives}

In line with the general objective of the study, the following specific objectives are developed

- To determine the effects of inadequate knowledge of professional accountants on IFRS adoption in Ethiopia

- To examine the effects of international financial reporting systems complexity on its adoption in Ethiopia

- To determine the effects of implementation cost on ifrs adoption in Ethiopia

\section{Review of Literature}

\subsection{Historical Development of International Financial}

Reporting Standards IFRS are an example of the second, capital market-oriented, system of financial reporting rules. (John Wiley \& Sons, Ltd. 2018) The original international standard setter, the International Accounting Standards Committee (IASC) was formed in 1973, during a period of considerable change in accounting regulation. In the US, the FASB had just been created, in the UK the Accounting Standards Committee had recently been set up, the EU was working on the main plank of its own accounting harmonization plan (the Fourth Directive), and both the UN and the Organization for Economic Co-operation and Development (OECD) were shortly to create their own accounting committees. The IASC was launched in the wake of the 1972 World Accounting Congress (a five-yearly get-together of the international profession) after an informal meeting between representatives of the British profession (the Institute of Chartered Accountants in England and Wales-ICAEW) and the American profession (the American Institute of Certified Public AccountantsAICPA).A rapid set of negotiations resulted in the professional bodies of Canada, Australia, Mexico, Japan, France, Germany, the Netherlands and New Zealand being invited to join with the US and UK to form the international body. Due to pressure (coupled with a financial subsidy) from the UK, the IASC was established in London, where its successor, the IASB, remains today. Historically, a major criticism of IFRS had been that it essentially endorsed all the accounting methods then in wide use, effectively becoming a "lowest common denominator" set of standards. (John Wiley \& Sons, Ltd. 2018) The trend in national GAAP had been to narrow the range of acceptable alternatives, although uniformity in accounting had not been anticipated as a near-term result. The IOSCO agreement energized IASC to improve the existing standards by removing the many alternative treatments which were then permitted under the standards, thereby improving comparability across reporting entities. The IASC launched its Comparability and Improvements Project with the goal of developing a "core set of standards" that would satisfy IOSCO. These were complete by 1993, not without difficulties and spirited disagreements among the members, but then - to the great frustration of the IASC - the standards were not accepted by IOSCO. Rather than endorsing the standard-setting process of IASC, as was hoped for, IOSCO appeared to want to cherry-pick individual standards. Such a process could not realistically result in near-term endorsement of IFRS for cross- border securities registrations. Ultimately, the collaboration was re launched in 1995, with IASC under new leadership, and this began a further period of frenetic activity, where existing standards were again reviewed and revised, and new standards were created to fill perceived gaps in IFRS. This time the set of standards included, among others, IAS 39, on recognition and measurement of financial instruments, which was endorsed, at the very last moment and with great difficulty, as a compromise- and purportedly interim - standard. At the same time, the IASC had undertaken an exercise to consider its future structure. In part, this was the result of pressure exerted by the US SEC and also by the US private sector standard setter, the FASB, both of which were seemingly concerned that IFRS were not being developed by "due process." While the various parties may have had their own agendas, in fact the IFRS were in need of strengthening, particularly in the way of reducing the range of diverse but accepted alternatives for similar 
transactions and events. The challenges presented to IASC would ultimately serve to make IFRS stronger. (John Wiley \& Sons, Ltd. 2018) If IASC was to be the standard setter endorsed by the world's stock exchange regulators, it would need a structure which reflected that level of responsibility. The historical Anglo-Saxon standard-setting model-where professional accountants set the rules for themselves-had largely been abandoned in the twenty-five years since the IASC was formed, and standards were mostly being set by dedicated and independent national boards such as the FASB, and not by profession-dominated bodies like the AICPA. The choice, as restructuring became inevitable, was between a large, representative approach-much like the existing IASC structure, but possibly with national standard setters appointing representatives - or a small, professional body of experienced standard setters which worked independently of national interests. The end of this phase of international standard setting, and the resolution of these issues, came about within a short period in 2000. In May of that year, IOSCO members voted to endorse IASC standards, albeit subject to a number of reservations (see discussion later in this chapter). This was a considerable step forward for the IASC, which itself was quickly exceeded by an announcement in June 2000 that the European Commission intended to adopt IFRS as the requirement for primary listings in all member states. This planned full endorsement by the European Union (EU) eclipsed the lukewarm IOSCO approval, and since then the EU has appeared to be the more influential body insofar as gaining acceptance for IFRS has been concerned. Indeed, the once-important IOSCO endorsement has become of little importance given subsequent developments, including the EU mandate and convergence efforts among several standard-setting bodies. In July 2000, IASC members voted to abandon the organization's former structure, which was based on professional bodies, and adopt a new structure: beginning in 2001, standards would be set by a professional board, financed by voluntary contributions raised by a new oversight body.

\subsection{Adoption International Financial Reporting Standards}

Adoption of IFRS assists a country in several ways. First of all it increases the amount of foreign investment that a country receives from external investors. Uniform accounting standards reduces the information asymmetry between different countries. Host country investors already have certain informational advantages over the foreign investors. They are more aware of the economic opportunities in the country and can anticipate the future direction in terms of government policies. They also have better access to information than the foreign investors. Different accounting reporting standards put the foreign investors at a higher information disadvantage. The foreign users need time to be trained to understand the host country's GAAP. The training and time spent represent transaction costs that reduce the cash flows to the investors and cause them to require a higher rate of return from the investment (Young and Guenther, 2003). The pressure on the foreign investor to comply with the rules and regulations in the host country may delay the finalization of a deal between the local company and the foreign investors (Dikova, Sahib and Witteloostuijn, 2010). The adoption of IFRS by different countries therefore increases the level of foreign investment by reducing the information asymmetry (Gordon and Bovenberg, 1996). Where there are anomalies in the company's accounting information, it may signify the opportunity to make abnormal profits or it may signal to the foreign investor that the company is in some financial trouble. The multinationals also incur fewer costs in terms of audit fees and information technology costs causing the company to have more financial resources to invest in the company. If a multinational company has several subsidiaries in different companies it has to get auditors who are able to understand and assess the application of the financial standards in the different countries. Currently, the audit companies which are used frequently by the multinational companies are the big four comprising of Delloite, PWC, Ernst \& Young and KPMG. These companies have the required expertise and staffing in the different countries. If IFRS was to be adopted, it would increase the number of audit companies participating in auditing multinationals. The increased competition would reduce the audit costs. Compilation of the financial statements of the different subsidiaries would also be less time consuming and not require a lot of staff and expertise. International standards make the accounting work easier. The reduction in these costs reflects in the financial statements and the company will record higher profits. There would be increased economic growth in the developing countries. Recently developed countries have been outsourcing cheaper labour in developing countries where there are high unemployment rates. With harmonization of the accounting standards, the companies would even be more open to outsourcing professionals in the accounting departments. This would increase the foreign investments in these countries creating more employment opportunities leading to higher economic growth. There is the principal agency problem in companies where the investors have to trust that the senior management is taking care of the business well. Foreign investors may be uncomfortable with the application of the accounting standards in the host countries. They may feel that they have to appoint more directors from the countries that have adopted IFRS to work in the host country. The senior management of the company will therefore comprise of different foreign professionals. These positions could have been given to qualified experts in the host country. In general, the reluctance to adopt the IFRS leads to lesser foreign investment and lost employment opportunities. There will be increased competition among the companies in the different countries leading to innovation. The foreign 
companies are armed with the capability of comparing the financial statements of different companies in different countries with the adoption of IFRS. The companies that have experienced increased capital flows and trading activities will realise that as more and more countries adopt IFRS, there will be increased competition for foreign investments. These companies have to perform better. They have to be innovative in the market place in terms of the customer service, product quality and differentiation in the products they offer in the market place. Higher profits signify attractive financial statements to the investors. The adoption of IFRS also reduces the cost of equity. The investors have access to accounting information of the company lowering the risk of acquiring the asset. When there is harmonization of accounting standards the investors understand the accounting statements more. They are able to perceive the risk of the investment appropriately. Where local accounting standards are used, the complexity makes the investments seem riskier. The investors may have an issue with relying on the regulatory oversight body in the country and the company's auditors and accountants. The investors are aware of the challenges that auditors face while dealing with company accountants using aggressive accounting principles. Harmonization of standards causes the investors to weigh the risks well lowering the risk of investment which ultimately leads to lower costs of equity. The investors are more willing to accept lower returns from the host company. Information has been observed to affect the prices of the company's assets. The company has an opportunity to influence the cost of its capital by providing detailed accounting information to its investors. The companies also have access to a larger pool of capital raising their liquidity and the amount of capital it can raise in the market (Covrig, Defond and Hung, 2007) In countries that have adopted IFRS, there has been an increase in the trading activities. The lower costs of equity also attract more investors. The adoption of IFRS reduces the occurrence of financial or economic crises. The international standards make the financial statements very transparent minimising the risk of senior management getting involved in manipulation of provisions and creating hidden reserves (Iatridis, 2010). They find it hard to participate in earnings management where they "smoothen" the earnings and hide the company losses in order to present a favourable financial position to the public. In a research study conducted in 2007, the companies that had adopted IFRS exhibited lesser evidence of earnings management and more timely loss recognition (Ball and Shivakumar, 2005). 2.3. The Current Structure According to (John Wiley \& Sons, Ltd. 2018). The formal structure put in place in 2000 has the IFRS Foundation, a Delaware corporation, as its keystone (this was previously known as the IASC Foundation). The Trustees of the IFRS Foundation have both the responsibility to raise funds needed to finance standard setting, and the responsibility of appointing members to the International Accounting Standards Board (IASB), the IFRS Interpretations Committee (IFRIC) and the IFRS Advisory Council (AC). The structure was amended to incorporate the IFRS Foundation Monitoring Board in 2009, renaming and incorporating the SME Implementation Group in 2010 as follows:

\subsection{Factors Affecting the Adoption of IFRS}

(UNCTAD 2008) a country case study was conducted by UNCTAD and The country case studies cover Brazil, Germany, India, Jamaica, Kenya, Pakistan, South Africa and Turkey. The objective of the case study was, to identify practical challenges in the Implementation of IFRS as requested by International Standards of Accounting and Reporting (ISAR) as it has recognized the growing number of member States that are introducing international financial reporting standards (IFRS) as basis for the preparation of corporate financial reports. The countries have taken a variety of approaches to implementing IFRS. In the case of Brazil, the implementation of IFRS had come into effect in 2010. German companies started preparing financial statements based on international accounting standards (IAS) beginning in the early 1990s. The approach in India has been to adapt IFRS to the economic realities of the country. Jamaica started implementing IFRS in 2002, while Kenya began the implementation process in 1998. Pakistan started introducing IAS issued by the International Accounting Standards Committee (the processor of the IASB) as early as in the 1970s. South Africa initiated a similar process in 1993. In Turkey, the process began in 2003. One of the critical elements in the implementation of IFRS is the rigorous enforcement of standards. The full benefits of a global set of financial reporting standards such as IFRS will be realized only when these standards are consistently enforced. Thus, IFRS consist of only one element of the financial reporting infrastructure. The institutions responsible for enforcing IFRS need to realize that, as a result of the growing globalization of financial markets, their enforcement efforts often protect both domestic and international investors. (UNCTAD 2008) Switching to IFRS involves to some degree a leap of faith. A strong national enforcement regime is essential to realise the potential benefits of adopting global accounting standards. (ICAWE 2015) Practical implementation of IFRS requires adequate technical capacity among preparers, auditors, users and regulatory authorities. The factors that initially contributed to the introduction of IFRS in the countries covered in the case studies vary. In Brazil, the Central Bank's intention is to bring financial reporting in line with international best practice to facilitate the comparability of financial reports and fostering investor confidence. In Germany, a number of large companies began to prepare their financial statements in accordance with IAS, not because they were required by national regulators, but in order to be able to access financial markets outside Germany. In 1998, German lawmakers gave listed companies the 
option of preparing their consolidated financial statements in accordance with IAS. The implementation of IFRS for the preparation of consolidated financial statements of listed companies in Germany became mandatory following the decision of the European Union to implement the IAS Regulation of 2002. The case study of Germany illustrates a European-Union-wide approach to implementing IFRS. Therefore, the implementation challenges extend beyond domestic factors. The main practical challenges that arise in implementing IFRS that have been identified through the country case studies and the lessons learned are generalised as depending on the general economic situation, existing regulatory framework and financial reporting tradition of a given member State, practical implementation of IFRS poses considerable challenges. These practical challenges relate to the coherence of the regulatory framework and the state of preparation of relevant institutions, enforcement and technical capacity.

\subsection{What Outcomes Result From Organizational Readiness for Change?}

We are on the way of studying readiness for change. But the question is how and why it is going to be studied. One suggestion is that when organizational readiness for change is high, organizational members are more likely to initiate change like instituting new policies, procedures, or practices; they exert greater effort in supporting the change and exhibit greater persistence in the face of obstacles or setbacks during implementation (Gist, 1992). In addition to this theory other suggests when organizational readiness is high, organizational members will exhibit more pro-social, change related behavior like action supporting more than the job expects (Herscovitch, 2002). And he also conceptualizes organizational readiness as a configure property and theorizes about the determinants and outcomes of intra organizational variability in readiness perceptions (Klein, 2000). (Weiner, 2009) theory of organizational readiness for change article in 2009 noted the characteristics for the instrument or measurement of readiness for organizational change as follows: - Some means of focusing respondents' attention on a specific impending organizational change, perhaps by including a brief description of the change in the survey instrument and by mentioning the change by name in the instructions for specific item sets. - Group referenced rather than self-referenced items that focus on group commitment and capabilities.

- Items that only capture change commitment or change efficacy.

- Efficacy items that are tailored to the specific organizational change, yet not so tailored that that the instrument could be used in other circumstances without substantial modification. Organizational change is not changing the organization itself but it is changing the policy, procedure, practice or trends of the organization. Implementing IFRS is transition of accounting standard from the previous local standard to the global accounting standard (Pacter, 2015). This means the organizational change is accounting policy change or in other word IFRS implementation is considered as organizational change. According to Weiner BJ's forth characteristics noted that the researcher uses his measurements of readiness for organizational change by adding few modifications and adding some other IFRS related contents for the current research. As the researcher have also mentioned earlier there are change experts who study about the issue. Depending on their theories and suggestions this research outcome will be effective.

\subsection{Benefits of IFRS Adoption}

It is advocated that adoption of IFRS will lead to greater transparency and understandability, lower cost of capital to companies and higher share prices ( due to greater confidence of investors and transparent information), reduced national standard setting costs, ease of regulation of security markets, easier comparability of financial data across borders and investment opportunities, increased credibility of domestic markets to foreign capital providers and potentials to foreign merger partners. It will also facilitate easier international mobility of professional staffs across national boundaries (Odia,J.O \& Ogiedu,K.O,2013). Armstrong et al. (2007) found that investors expected net benefits to IFRS adoption in Europe associated with increases in information quality, deceases in information asymmetry, more rigorous enforcement of the standards and convergence. Gordon (2008) listed the benefits from adaptation of IFRS in the world as: better financial information for shareholders and regulators, enhanced comparability, improved transparency of results, increased ability to secure cross border listing, better management of global operations and decreased cost of capital in the world. According to Ball (2006), IFRS has direct and indirect benefits to investors. The direct benefits to investors include the following:

1. IFRS provides more accurate, comprehensive and timely financial statement information for public financial reporting in most of the IFRS adopted countries when compared to the national standards they replace.

2. Improving financial reporting quality allows small investors to compete better with professionals, and hence reduces the risk they are trading with a better informed professional ('adverse selection').

3. By eliminating many of the international differences in accounting standards, IFRS eliminates many of the adjustments which have been made historically by analysts in order to make the companies' financial reports more comparable internationally. And hence, IFRS adoption could reduce the costs of financial information processing to investors. 
4. Reduction in the financial information processing cost increases market efficiency.

5. Reducing international differences in accounting standards contributes to some degree in removing barriers to cross boarder acquisitions and divestures. Generally, IFRS provides increased comparability and hence reduced information costs and information risk to investors (Ball, 2006). The indirect benefits of IFRS adoption include the following: According to Ball (2006), IFRSs offer several indirect advantages to investors. Since higher information quality should reduce both the risk to all investors from owning shares and the risk to less informed investors due to adverse selection, in theory it should lead to a reduction in firm's costs of equity capital. This would increase share prices and in turn makes new investments attractive to investors other factors remaining constant. Indirect IFRS advantages to investors arise from improvement in the usefulness of financial statement information in contracting between firms and a variety of stakeholders, notably lenders and managers (Watts, 1977; Watts and Zimmerman, 1986). According to UNCTAD, several developing countries and countries with economies in transition strive to mobilize financial resources from domestic and international sources to achieve their social and development goals. Hence, the availability of relevant information on potential investment targets has an impact on efforts to mobilize investment for financing economic and social development; such information plays an important role to make investment decisions and conduct risk assessment (UNCTAD, 2008). Companies which provide potential investors with reliable and comparable financial statements are more likely to attract domestic and international investment.

\subsection{Historical Background of Accounting in Ethiopia}

According to Firdawok Teshome (2017) the evolution of accounting can be seen from international perspective and from national point of view. While the development of accounting internationally has generally been well documented, studies that examine this process in developing countries appear relatively limited (Mihret, 2009 citied by Firdawork). The development of accounting in Ethiopia could be better understood if examined in a range of decades beginning from pre-1970s to date. Ethiopia has had alternating political orders: from a developing market economy (pre 1974) to a communist economy (1974 through to 1991), and then back to a market oriented economy (1991 onwards) (Mihret, 2009). The development of accounting in Ethiopia seems to exhibit distinct patterns during the three chronological periods: Pre-1974, 1974 to 1991, and post-1991. These patterns are described below in terms of stakeholderse efforts to promote the development of accounting and the outcomes of such efforts. According to Kinfu (1990) the establishment of the commercial school in 1943 provided an important only venue for training of would be office clericals in commercial subjects such as banking, secretarial and finance. These graduates in the area of banking, secretarial and finance did try to form some type of association with a view to establish a link among them. Another development in the 1940s was the start of public accounting in Ethiopia. This is traced to events when British accounting firms, like Price Waterhouse and Peat, opened branches in the country (Mihret, 2009). Two significant developments in the history of accounting in Ethiopia took place in the 1960s. In 1960 the Commercial Code of Ethiopia was proclaimed (Government of Ethiopia 1960) which was followed by the formation of the Office of the Auditor General (OAG) in 1961 by Proclamation 199/1961 (Government of Ethiopia, 1961). The commercial Code contains accounting and external auditing provisions, which serve as the legal basis for financial reporting and external audit of companies (Argaw, 2000; Kinfu, 1990; ROSC, 2007). The early seventies saw the creation of many professional associations in Ethiopia (Mengistu, 2008). An effort to establish indigenous professional accounting associations in Ethiopia occurred in 1973 when the Ethiopian Professional Association of Accountants and Auditors (EPAAA) was established (Argaw, 2000; Kinfu, 1990; Mihret, n.d). According to Mihret (2009), the EPAAA was aspiring to develop to a level where it would certify and license public accountants to practice in Ethiopia. Composition of members to the association included mainly accounting and auditing practitioners. In 1974, a military government came into power in Ethiopia and declared a communist ideology. Most people agree that this period (up to 1991) was a time when the development of accounting appears to have been held back (Argaw, 2000; Blake, 1997; Kinfu, 2005). Nonetheless, an important landmark in the history of accounting and auditing in this period was the formation of the Audit Service Corporation (ASC) by Proclamation 126/1977 (Government of Ethiopia, 1977) (Mihret, 2009). The year 2014 marked significant water shed in Ethiopia's financial reporting as the country wholly adopts international Financial Reporting Standards (IFRS) as its financial reporting framework. With the growing internationalisation of economic trade and the globalisation of businesses and financial markets, financial information prepared and audited in traditional/rule based accounting and auditing system may no longer satisfy the needs of users whose decisions are more international in scope (Zeghal and Mhedhbi, 2006) ; (Carson and Dowling, 2010). As a result of the increasing popularity of participating in the global economy investors are becoming increasingly interested in emerging markets as they present a diversified opportunity according to Levich (2001). Similar to many developing countries, Ethiopia's financial reporting practices are driven by its tax laws and fragmented accounting practices acquired from the country's institutions of higher learning. Implementing IFRS as a national standard will have significant benefits and challenges for countries to improve corporate transparency that is 
required by investors and the public. Many countries are currently migrating to IFRS by abandoning their national accounting standards. This is an opportunity for countries like Ethiopia, which do not have national accounting standards even if transiting to international standards with weak financial reporting practices in the country may pose many challenges that must be overcome through time (Gizaw, n.d).

\section{METHODOLOGY OF THE STUDY}

The researcher used qualitative research approach. There are three research approaches. The quantitative approach provides an objective measure of reality, on the other hand, the qualitative approach allows the researcher to explore and better understand the complexity of a phenomenon. Both quantitative and qualitative research approaches may have their own strengths and limitations. According to Sale et al, (2012)

\subsection{Type and Sources Data}

This study used secondary data and the data was obtained from a review of relevant documents and articles.

\subsection{Document Review}

The documents were reviewed by referring most recent information from authorized documents and different reports. Annual reports, legislations, directives and other documents related to the adoption and importance of IFRS were used. The document reviews were used to triangulate the data collected by the questionnaires and interviews.

\subsection{Application of Meta-Analysis}

Meta-analysis aims to combine information across separate but similar studies. Most meta analyses are based on one of two statistical models, the fixed-effect model or the random-effects model. Under the fixed-effect model it assumes that there is one true effect size that the true effect could vary from study to study.

\subsection{Qualitative Meta analysis}

Meta-Analyses are used to pool the results of individual studies. Findings from various individual studies are analyzed statistically by strict procedures. It is an intentional and coherent approach to analyz data across qualitative studies. It is a process that enables researchers to identify a specific research question and then search for, select, appraise, summarize, and combine qualitative evidence to address the research question. It is interpretive analytical technique that uses the qualitative findings reported in previous studies as building blocks for gaining a deeper understanding of particular phenomena. The following articles were major sources of the review

\begin{tabular}{|l|l|l|l|l|}
\hline No. & Author & Title & Year & Major findings \\
\hline 1 & $\begin{array}{l}\text { Atu g., Raphael } \\
\text { A. \& Atu G. }\end{array}$ & $\begin{array}{l}\text { Challenges of the } \\
\text { implementation of IFRS } \\
\text { in less developed } \\
\text { countries }\end{array}$ & 2016 & $\begin{array}{l}\text { political, legal, cultural, financial and } \\
\text { economical aspects are challenging for } \\
\text { IFRS adoption in less developed countries }\end{array}$ \\
\hline 2 & Tesfu & $\begin{array}{l}\text { Benefits and challenges } \\
\text { of adoption IFRS in } \\
\text { Ethiopia }\end{array}$ & 2012 & $\begin{array}{l}\text { Need for training, complexity of IFRS and } \\
\text { lack of implementation guidance are the } \\
\text { major challenges of IFRS adoption. }\end{array}$ \\
\hline $\mathbf{3}$ & Fikru Fentahun & $\begin{array}{l}\text { The adoption of (IFRS) } \\
\text { in Ethiopia: }\end{array}$ & 2012 & $\begin{array}{l}\text { High cost of adopting, the complex nature, } \\
\text { lack of proper instructions from regulatory } \\
\text { bodies for implementing IFRS, as well as } \\
\text { IFRS's emphasis on fair value accounting, } \\
\text { are listed among the most important } \\
\text { challenges of IFRS adoption }\end{array}$ \\
\hline 4 & Demaki & $\begin{array}{l}\text { prospects and challenges } \\
\text { of IFRS to economic } \\
\text { development in Nigeria }\end{array}$ & 2013 & $\begin{array}{l}\text { The need of amendment of laws and } \\
\text { regulation is among the major challenges } \\
\text { of IFRS adoption }\end{array}$ \\
\hline 5 & Alemi & $\begin{array}{l}\text { IFRS adoption progress } \\
\text { in Ethiopia }\end{array}$ & 2016 & $\begin{array}{l}\text { shortage of qualified professionals and } \\
\text { lack preparedness are the major challenges } \\
\text { of IFRS adoption, }\end{array}$ \\
\hline 6 & Mohamed Zakari & $\begin{array}{l}\text { Challenges of IFRS } \\
\text { adoption in Libya }\end{array}$ & 2014 & $\begin{array}{l}\text { Accounting education and economic } \\
\text { issues. }\end{array}$ \\
\hline
\end{tabular}

\section{Conclusion and Recommendation .}

\subsection{Conclusions}

The major objective of this study was determining the major challanges of International Financial Reporting 
Standards adoption in Ethiopia. There is no doubt that conversion to IFRS is a huge task and a big challenge, its revolutionary impact requiring a great deal of decisiveness and commitment.

Based on the secondary data gathered from related researchs, The major challenges of the adoption of IFRS in many countries is basically related with the complexity of IFRS principles, lack of adequate IFRS guidance, different approval principles does not implement with in the specified time, lack of availability of competent specialist, high level of training cost requirements, less familiarity with the IT, lack of proper instructions from regulatory bodies and problem of proper plan of financial institutions to implement IFRS.

Inspite of the challenges, adoption of the IFRS in many countries has various advantages. It will lead to increased foreign investment in different countries due to the increased foreign investment and economic stability. There will be decreased transaction costs such as training, accountancy and audit fees for the foreign investors. IFRS greatly reduces earnings manipulation as it increases the transparency of the financial statements.

\subsection{Recommendations}

Based on the results the researcher recommends that Raise awareness of professionals, regulators and preparers to improve the knowledge gap, before implementation adequate resources should be put in place to support the sustainable implementation of IFRS and before proceeding to implement or adopting the standards the stake holders should make a cost- benefit analysis

\section{References}

Armstrong, C., Barth, M., Jagolinzer, A.\&Riedl. E., (2007) Market reaction to the adoption of IFRS in Europe (Working paper), Stanford University

Baker, R.C. \& Barbu, E.M., (2007) Trends in research on international accounting harmonization, The International Journal of Accounting, Vol. 42, pp. 272-304.

Ball R., Robin, A \& Wu, JS, (2000) 'Accounting standards, the institutional environment and issuer incentives: Effect on timely loss recognition in China', Asia-Pacific Journal of Accounting and Economics Vol. 17 No.2 pp 71-96.

Ball, R., (1995) 'Making Accounting more International: Why, How and How Far wills it go?' Journal of Applied Corporate Finance, Vol 8, pp 19-29

Ball, R., (2001) Infrastructure Requirements for an Economically Efficient System of Public Financial Reporting and Disclosure, Brookings What tons Papers on Financial Services pp 127-69

Ball, R., (2006) 'IFRS: Pros and Cons for Investors' Accounting and Business Research International Accounting Policy Forum pp 5-27.

Ball,R.,Robin,A., \& Wu, J.S., (2003). Incentives versus standards: Properties of accounting income in four East Asian countries. Journal of Accounting and Economics, 29, 1 - 51.

Barth, M., Landsman W \& Lang, M,(2008) 'International Accounting Standards and Accounting Quality, Journal of Accounting Research, Vol. 46, No. 3, June pp. 467-498.

Cairns, D (2001): IAS Lite is alive and Well. Accountancy ,127 (May), 98-99

Chamisa, E. E., (2000) The Relevance and Observance of the IASC standards in Developing Countries and the Particular case of Zimbabwe, The International Journal of Accounting, 35(2), 267-286.

Chand, P., \& Patel, C., (2008). Convergence and harmonization of accounting standards in the South Pacific region.

Choi, F.D.S \& Meek .G.,(2005) International Accounting (5th Ed.) New York, NY: Prentice Hall

Daske, H, Hail, L,Leuz, C. \& Verdi R., (2008). Mandatory IFRS reporting around the World: Early Evidence on the Economic Consequences. Journal of Accounting and Research, 46(5) 1085- 1142

Guerreiro, M. A. S., Rodrigues, L. L., \& Craig, R., (2011). Essays on the Institutionalisation of a New Accounting Regime for Unlisted Companhies in Portugal.

Hlaciuc Elena, Mihalciuc Camelia Catalina, Cibotariu Irina Stefana \& ApetriAnisoaraNiculina (2009), some issues about the transition from U.S. Generally Accepted Accounting Principles (GAAP) to International Financial Reporting Standards (IFRS), Annales Universitatis Apulensis Series Oeconomica, 11(1)

Hoyle B., Schaefer E., and Doupnik S., (2009) Advanced Accounting, 9th edition, McGraw - Hill

IASB, (2009) International Financial Reporting Standards (IFRS) for Small and Medium size Enterprises (SMEs). London: IASB

Iyoha, F.O. \& Faboyede, S.O., (2011) Adopting international financial reporting standards (IFRS) a focus on Nigeria, International journal of research in commerce \& management volume no: 2 , issue no. 1 pp. 35-40

Jeanjean, T., \& Stolowy, H., (2008). Do accounting standards matter? An exploratory analysis of earnings management before and after IFRS adoption. Journal of Accounting and Public Policy, 27(6), 480-494. doi:10.1016/j.jaccpubpol.2008.09.008.

Jermakowicz Eva K., (2004): Effects of Adoption of International Financial Reporting Standards in Belgium: 
The Evidence from BEL-20 Companies, Accounting in Europe, 1:1, 51-70

Larson, R.K. \& Street, D.L, (2004). Convergence with IFRS in an expanding Europe: Progress and Obstacles identified by large Accounting Firms' Survey. Journal of International Accounting, Auditing and Taxation, 13, 89-119.

Mir, M. Z., \& Rahaman, A. S., (2005) The Adoption of International Accounting Standards in Bangladesh: An exploration of rationale and process. Accounting, Auditing and Accountability Journal, 18(6), 816-841

Nobes, C., (2006). The survival of international differences under IFRS: Towards a research agenda. Accounting and Business Research, 36 (3), 233-245.

Obazee J O., (2007). Current Convergence Efforts in Accounting Standard Setting and Financial Reporting: Lagos, Nigerian Accounting Standing Board. January 31.

Rong-Ruey D., (2006).Convergence of Taiwan's Financial Accounting Standards with International Financial Reporting Standards: Past, Present and Outlook. Accounting Research and Development Foundation,

Sale, et al., (2002) Revisiting the Quantitative-Qualitative Debate: Implications for Mixed Methods Research, Quality \& Quantity 36(1)

Siaga, S.F., (2012). Challenges to the Adoption of International Financial Reporting Standards in Africa ( MAGISTER COMMERCII Minor Dissertation). University of Johannesburg

Soderstrom, N.S \& Sun, K.J, (2007). IFRS adoption and Accounting Quality: A Review. European Accounting Review, 16 (4), 675-702.

Sunder, S., (2010) IFRS Monopoly: The Pied Piper of Financial Reporting, being paper prepared for information for better markets conference ICAEW ,London December 20-21,2010

Tsakumis, G.T., Campbell, D.R. \& Douphik .T.S., (2009) IFRS: Beyond the standards. Journal of Accountancy, 207 (2), 34-39

Tyrrall D., Woodward D., Rakhimbekova A., (2007). The relevance of International Financial Reporting Standards to a developing country: Evidence from Kazakhstan, University Of Illinois.

Winney,K. ,Marshall,D ..Bender,B \& Swiger,J (2011). Accounting Globalization: Roadblocks to IFRS Adoption in the United States. Global Review of Accounting and Finance, $167-178$

Zeghal, D. \& Mhedhbi K. (2006), An analysis of the factors affecting the adoption of international accounting standards by developing countries, Published by University of Illinois.

Zeghal, D. \& Mhedhbi K., (2006) An analysis of the factors affecting the adoption of international accounting standards by developing countries, Published by University of Illinois. 